\title{
Serum aldosterone and coronary artery disease
}

\author{
Vida Nesarhoseini ${ }^{2 *}$, Mehdi Rasooli ${ }^{1}$ and Mehrdad Taghipour ${ }^{2}$ \\ ${ }^{1}$ Department of Cardiology, Mazandaran University of Medical Sciences, Sari, Iran \\ ${ }^{2}$ Nephrology and Urology Research Center, Baqiyatallah University of Medical Sciences, Tehran, Iran
}

\begin{abstract}
Background and objective: The role of aldosterone is well studied in the patients with heart failure (HF) and acute myocardial infarction (MI). But little data is available about the level of aldosterone in patients with coronary artery disease (CAD). This study was designed to evaluate whether this relation is exist or not.

Methods: The study population consisted of 94 subjects aged 40-69 years who were referred to heart center of Mazandaran. The subjects were classified as CAD cases and controls according to the results of coronary angiography. The patients with acute MI, HF, hypertension, diabetes, inflammation and who used angiotensin converting enzyme inhibitors in recent two weeks were not included in the study.
\end{abstract}

Results: Forty nine patients had at least more the 50\% stenosis on one of epicardial coronary and the others were normal coronary. Serum aldosterone was found to be $161.6 \pm 1851 \mathrm{pg} / \mathrm{L}$ in patients with coronary artery disease $(\mathrm{CAD})$ and $123.8 \pm 68.3 \mathrm{pg} / \mathrm{L}$ in patients with normal coronary $(\mathrm{P}=0.201)$.

Conclusion: The results demonstrate that the level of aldosterone had not significant differences between the patients with and without CAD.

\section{Introduction}

Aldosterone is the major human mineralocorticoid which is released from adrenal cortex. Aldosterone regulates the reabsorption of sodium, chloride, water and blood pressure [1-3]. It also has effect on plasma bicarbonate via regulation of the secretion of hydrogen ion from renal tubular cells. Increasing evidence has suggested involvement of the aldosterone in endothelial dysfunction, macrophage oxidative stress, atherosclerosis, vascular inflammation and myocardial ischemia [2-6].

There is a relationship between increased plasma aldosterone and long-term mortality of patients with heart failure (HF) and acute myocardial infarction (MI) [7-13]. Clinical studies also demonstrated that aldosterone-receptor blockade reduces mortality and improve survival of the patients with heart failure. The findings of EPAESSUS (Eplerenone Post-Acute Myocardial Infarction Heart Failure Efficacy and Survival Study) and RALES (Randomized Aldactone Evaluation Study) showed that mineralocorticoid receptor blockade reduced morbidity and mortality of patient with left ventricular dysfunction after acute MI and heart failure [14]. There are several studies which demonstrated the role of aldosterone in mortality and morbidity of patients with MI and heart failure. But, there is a limited reports regarding the role of aldosterone in patient with CAD without acute MI or HF [1-3].

In this study we examined the relationship between aldosterone plasma level and coronary artery disease without acute MI or HF.

\section{Materials and methods}

The current research is a case-control study. The study population consists of 94 patients who were underwent coronary angiography in Mazandaran Heart Center. The exclusion criteria were: patients with $\mathrm{HF}$, myocardial infarction, hypertension, diabetes mellitus, history of using angiotensin-converting-enzyme (ACE) inhibitor in the last two weeks and elevated CRP. Hypertension was defined as a known blood pressure more than $140 / 90 \mathrm{mmHg}$ or using of antihypertensive drugs. Smoking was defined as ceased/unceased smoking.

Diabetes mellitus was defined as fasting glucose $\geq 126 \mathrm{mg} / \mathrm{dl}$, or using of hypoglycemic agents. Normal concentration of CRP in healthy human serum is usually lower than $3 \mathrm{mg} / \mathrm{L}$. Coronary artery disease was defined by coronary angiography; the presence of at least one stenosis $\geq$ $50 \%$ in at least 1 of 15 coronary segments of the three major coronary arteries. Serum $\mathrm{Na}^{+}$and $\mathrm{K}^{+}$were measured by electropotentiometry, hsCRP by using immunotorbidometry and cholesterol, triglyceride, and glucose by routine enzymatic methods. The concentration of serum aldosterone $(\mathrm{pg} / \mathrm{ml})$ was measured by radioimmunoassay (RIA) using Germany kit. High level of aldosterone was defined as 10-160 $\mathrm{pg} / \mathrm{mL}$. Study participants were divided into two groups of patients with coronary artery disease and normal coronary artery. Clinical and anthropometric characteristics of the participants were collected by questionnaire.

\section{Statistical analysis}

The results are presented as the means \pm SD and median (range) for normal and skewed distributed variables respectively. The significance of any differences between two groups was tested using the student's $\mathrm{t}$-test. All p- values are two-tailed and differences were considered significant if $\mathrm{p}$-values were $\leq 0.05$. All data were analyzed using SPSS

Correspondence to: Vida Nesarhoseini, MD, Nephrology and Urology Research Center, Baqiyatallah University of Medical Sciences, Molla Sadra Ave, Vanak Sq. Tehran, IR Iran, Tel: +98- 2181262073, Fax: +98-2181262073, E-mail: mehrdadtaghipour@gmail.com

Key words: aldosterone, CAD, diabetes, hypertension

Received: November 27, 2016; Accepted: December 19, 2016; Published: December 22, 2016 
16.0 (Statistical Package for Social Sciences, Inc., Chicago, IL).

\section{Result}

The baseline characteristics of the study population are displayed in Table 1. From all patients who underwent angiography, 49 patients had significant atherosclerotic lesions. The mean age of the participants in patient and control group was $58.94 \pm 10.46$ and $50.22 \pm 9.35$ respectively. About $59.2 \%$ in patients group and $42.2 \%$ in control group had a history of angina (Table 2). The mean level of aldosterone was $161.6 \pm 185.1$ and $123.8 \pm 68.3 \mathrm{pg} / \mathrm{mL}$ in patients and control groups respectively. There was no significant relationship between the level of serum aldosterone and coronary artery diseases $(\mathrm{p}=0.201)$. Body mass index, age, blood glucose were considered as independent risk factor for coronary artery disease.

\section{Discussion}

The results of the present study showed that serum aldosterone concentration is not associated with CAD in patients undergoing coronary angiography. However, other investigators reported that serum aldosterone is independently associated with CAD even below the levels suggestive of hyperaldosteronism i.e. in the normal range [15]. Analysis of causes of death relating to CAD showed that aldosterone is related to a higher risk of sudden cardiac death (SCD) and fetal stroke and correlated with CAD mortality in patients with acute coronary syndrome (ACS) with normal or minimally impaired LV function. It is also reported that patients with impaired LV function are at higher risks for cardiovascular death as opposed to patients with normal LV function [16]. The current results did not show the aldosterone effect on cardiovascular mortality or morbidity. This may be due to our patient's age and ethnicities difference or genetic difference. Our data indicated that serum aldosterone level within the physiological range may not relate with CAD.

Table 1. Demographic and clinical characteristics in CAD controls and patients. The continuous and categorical variables were compared by $\mathrm{t}-$ and $\chi^{2}$-tests, respectively. The number in each group has shown in parentheses. The results are presented as the means ${ }^{ \pm}$ $\mathrm{D}$ and median (range)

\begin{tabular}{|l|c|c|c|}
\hline Variables & $\begin{array}{c}\text { With CAD } \\
(\mathrm{n}=49)\end{array}$ & $\begin{array}{c}\text { Without CAD } \\
(\mathrm{n}=45)\end{array}$ & P \\
\hline Age (year) & $50.2 \pm 9.4$ & $58.9 \pm 10.5$ & 0.001 \\
\hline Male gender & $35(71.4)$ & $14(31.1)$ & 0.001 \\
\hline BMI $\left(\mathrm{kg} / \mathrm{m}^{2}\right)$ & $29.1 \pm 4.9$ & $26.7 \pm 2.8$ & 0.004 \\
\hline Disease History : Angina & $29(59.2)$ & $19(42.2)$ & 0.01 \\
Gastric ulcer & $2(4.1)$ & $2(4.4)$ & 0.926 \\
\hline Smoking & $43(87.8)$ & $43(95.6)$ & 0.817 \\
\hline Physical activity Low & $11(22.4)$ & $9(20.0)$ & 0.45 \\
\hline Moderate & $18(36.7)$ & $20(44.4)$ & 0.52 \\
\hline Excessive exercise & $20(40.8)$ & $16(35.6)$ & 0.43 \\
\hline Alcohol consumption & $2(4.41)$ & $0(0)$ & - \\
\hline Drug history & $4(8.2)$ & $1(2.2)$ & 0.01 \\
\hline
\end{tabular}

Table 2. Laboratory documents of the CAD cases and controls.

\begin{tabular}{|l|c|c|c|}
\hline \multicolumn{1}{|c|}{ Group } & $\begin{array}{c}\text { Case } \\
(\mathrm{N}=49)\end{array}$ & $\begin{array}{c}\text { Control } \\
(\mathrm{N}=45)\end{array}$ & P-value \\
\hline Aldosterone & $161.6 \pm 185.1$ & $123.8 \pm 68.3$ & 0.201 \\
\hline Sodium $(\mathrm{mEq} / \mathrm{L})$ & $138.7 \pm 3.0$ & $138.8 \pm 3.0$ & 0.833 \\
\hline Potassium $(\mathrm{mEq} / \mathrm{L})$ & $4.5 \pm 0.7$ & $4.3 \pm 0.3$ & 0.087 \\
\hline Cholesterol $(\mathrm{mg} / \mathrm{dL})$ & $190.7 \pm 48.2$ & $177.7 \pm 46.3$ & 0.187 \\
\hline Triglyceride $(\mathrm{mg} / \mathrm{dL})$ & $218.1 \pm 147.7$ & $159.8 \pm 73.3$ & 0.019 \\
\hline Glucose $(\mathrm{mg} / \mathrm{dL})$ & $106.1 \pm 23.8$ & $92.0 \pm 12.2$ & 0.001 \\
\hline CRP $(\mathrm{mg} / \mathrm{L})$ & $1.86 \pm 0.35$ & $1.96 \pm 0.20$ & 0.107 \\
\hline Systolic $\mathrm{pressure}(\mathrm{mmHg})$ & $120.4 \pm 12.2$ & $117.9 \pm 10.7$ & 0.292 \\
\hline
\end{tabular}

It has shown that secondary hyperaldosteronism due to the increased rennin-angiotensin aldosterone activity is associated with higher mortality nn patients with chronic heart failure (CHF) and acute MI, [17] Connell, et al. and Jafe, et al. proposed that circulating glucocorticoid levels might activate the mineralocorticoid receptor $[18,19]$. It has pro-inflammatory, pro-thrombotic and pro-fibrotic effects which are contributed to the development of atherosclerosis and CAD which is contrary to our study. Therefore, blocking the aldosterone receptors has beneficial effects on cardiovascular system. A big part of the benefits of mineralocorticoid receptors blockade has been attributed to the reduction of sudden cardiac death. Aldosterone increases the cardiac arrhythmia and may increase sympathetic drive, decreases heart rate variability and has effect on electrolyte homeostasis $[14,20]$. Therefore, because current treatments with hypolipidemic drugs and ACE inhibitors do not decrease the level of aldosterone, the risk of cardiovascular diseases exists.

\section{Conclusion}

Our results indicated the aldosterone level has not an important role in the development of fatal CVD events. So treatment by blocking the receptors of mineralocorticoids has no benefits in preventing of CVD events.

\section{Limitation and strength}

The patients in this study were middle aged $(58 \pm 10)$, because our county is young. But the European sample was elderly and generalization to other ethnicities and younger individuals cannot be male.

\section{Acknowledgments}

Authors gratefully acknowledge the assistance of all participants in this study and also all staff members of cardiology clinic of Mazandaran heart center.

\section{Conflicts of interest}

None of the contributing authors have any conflict of interest, including specific financial interests or relationships and affiliations relevant to the subject matter or materials discussed in the manuscript.

\section{References}

1. Dorlands Medical Dictionary: Coronary artery disease. Retrieved 2009-01-09.

2. Thomas AC, Knapman PA, Krikler DM, Davies MJ (1988) Community study of the causes of "natural" sudden death. BMJ 297: 1453-1456.[Crossref]

3. American Heart Association: Heart disease and stroke statistics-2007 update. AHA, Dallas, Texas, 2007

4. Lanza GA (2007) Cardiac syndrome X: a critical overview and future perspectives Heart 93: 159-166.[Crossref]

5. Thomas AC, Knapman PA, Krikler DM, Davies MJ (1988) Community study of the causes of "natural" sudden death. BMJ 297: 1453-1456.[Crossref]

6. Lloyd-Jones D, Adams RJ, Brown TM, Carnethon M, Dai S, et al. (2010) on behalf of the 297 American Heart Association Statistics Committee and stroke Statistics subcommittee. Heart disease and stroke statistics-2010 update. A report from the American Heart Association. Circulation 121: 948-954.

7. Kasper D.L, Braunwald E, Fauci AS, et al. (2005) Harrison's principles of internal medicine. 16th edition, MC Graw, Hill, New York: 226-227.

8. Sadeghi M, Ruhafza H, ShiraniSh, AkhavanTabib A, Aghdak P, et al. (2006) The prevalence of coronary artery disease according to rose questionnaire and ECG: Isfahan Healthy Heart Program (IHHP). ARYA Journal Atherosclerosis 2: 70-74.

9. Hatmi ZN, Tahvildari S, GafarzadehMotlag A, SabouriKashani A (2007) Prevalence 
of coronary artery disease risk factors in Iran: a population based survery. $B M C$ Cardiovasc Disord 30: 7-32. [Crossref]

10. Jolly S, Vittinghoff C, Chattopadhyay A, Bibbins-Domingo K (2010) Highercardiovascular disease prevalence and mortality among younger blacks compared to whites. The American Journal of Medicine 123: 811-818. [Crossref]

11. Simons M, Bonow RO, Chronos NA, Cohen DJ, Giordano FJ, et al. (2000) Clinical trials in coronary angiogenesis: issues, problems, consensus: An expert panel summary. Circulation 102: E73-86. [Crossref]

12. Stegman TJ (2007) Protein promise in heart disease. GCPJ: 21-24.

13. Shah NC, Pringle S, Struthers A (2006) Aldosterone blockade over and above ACEinhibitor in patients with coronary artery disease but without heart failure. $J$ renin Angiotensin Aldosterone Sys7: 20-30. [Crossref]

14. Funder JW (2005) ACE inhibitors and mineralocorticoid receptor blockade in patients with congestive heart failure. Curr Diab Rep 5: 36-40.[Crossref]

15. Tomaschitz A, Pilz S, Ritz E, Meinitzer A, Boehm BO, et al. (2010) Plasma aldosterone levels are associated with increased cardiovascular mortality: the Ludwigshafen Risk and Cardiovascular Health (LURIC) study. Eur Heart J 31: 1237-1247. [Crossref]
16. Tomaschitz A, Pilz S, Ritz E, Grammer T, Drechsler C, et al. (2011) Association of plasma aldosterone with cardiovascular mortality in patients with low estimated GFR: the Ludwigshafen Risk and Cardiovascular Health (LURIC) Study. Am J Kidney Dis 57: 403-414.[Crossref]

17. Terry KW Ma, Kevin KH Kam, Bryan P Yan, Yat-Yin Lam (2010) Renin-angiotensinaldosterone system blockade for cardiovascular diseases: current status. Br J Pharmacol 160: 1273-1292. [Crossref]

18. Connell JM, MacKenzie SM, Freel EM, Fraser R, Davies E (2008) A lifetime of aldosterone excess: long-term consequences of altered regulation of aldosterone production for cardiovascular function. Endocr Rev 29: 133-154. [Crossref]

19. Jaffe IZ, Tintut Y, Newfell BG, Demer LL, Mendelsohn ME (2007) Mineralocorticoid receptor activation promotes vascular cell classification. Arterioscler Thromb Vasc Biol 27: 799-805.

20. Beygui F, Labbé JP, Cayla G, Ennezat PV, Motreff P, et al. (2013) Early mineralocorticoid receptor blockade in primary percutaneous coronary intervention for ST-elevation myocardial infarction is associated with a reduction of life-threatening ventricular arrhythmia. Int J Cardiol 167: 73-79. [Crossref]

Copyright: (02016 Nesarhoseini V. This is an open-access article distributed under the terms of the Creative Commons Attribution License, which permits unrestricted use, distribution, and reproduction in any medium, provided the original author and source are credited. 